\title{
Compliance en innovatie
}

\section{Inleiding themanummer}

Roger Dassen
Compliance en innovatie. Twee thema's waarvan de natuurlijke samenhang misschien niet onmiddellijk voor de hand ligt. Op het eerste oog lijken het immers twee werelden, een reactieve en een proactieve. Compliance wordt in de (van De Nederlandsche Bank afkomstige) Regeling Organisatie en Beheersing gedefinieerd als 'de naleving van wet- en regelgeving, alsmede het werken volgens de normen en regels die een instelling zelf heeft opgesteld'. Daarmee is de verleiding groot om compliance te zien als reactief. Er gebeurt iets, er wordt regelgeving ontwikkeld, bedrijven implementeren die regelgeving in de vorm van interne normen, regels en processen, en compliance ziet op de naleving daarvan. Plaats daar tegenover het begrip 'innovatie', door het Amerikaanse US Commerce Department gedefinieerd als 'design, invention, development, and/ or implementation of new or altered products, services, processes, systems, organizational structures, or business models for the purpose of creating new value for customers and financial returns for the firm.' Een begrip dat juist het proactieve benadrukt. Sterker nog, men zou zelfs kunnen beargumenteren dat innovatie wordt tegengehouden door regelgeving en compliance. De autonome Google-car, een groot aantal biogenetische ontwikkelingen zijn twee voorbeelden van innovaties die technisch gezien nagenoeg implementatie-rijp zijn, maar waar wet- en regelgeving waarschijnlijk een zeer serieuze vertraging in de marktintroductie gaan opleveren.

Toch passen de twee begrippen uitstekend bij elkaar. In de huidige tijd, die wordt gekenmerkt door een hoog veranderingstempo als gevolg van voornamelijk technologische ontwikkelingen, zijn standaardregels niet toereikend. Organisaties moeten daarenboven varen op een moreel kompas, dat juist in tijden van verandering leidt tot het juiste gedrag. De eerste twee artikelen gaan over de inrichting van de compliance-functie binnen een organisatie, en beschouwen hoe de compliance-functie aan dat uitgangspunt invulling kan geven. Bleker-van Eyk maakt onderscheid tussen compliance in de financiële en de niet-financiële sector. Voor de niet-financiële sector ziet zij de compliance-functie nog redelijk in de kinderschoenen staan. Een unieke mogelijkheid om de functie innovatief in te vullen. In dat kader kan worden geleerd van de ervaring in de financiële sector, waar Bleker-van Eyk zich zorgen makt over de teruglopende aandacht die compliance en integriteit krijgen. Tegenover het grote belang dat wordt toegekend aan solvabiliteit en liquiditeit staat volgens haar een te geringe en bovendien verkeerd gefocuste aandacht voor compliance. Niet alleen worden compliance-afdelingen hard getroffen door bezuinigingen, bovendien constateert Bleker-van Eyk dat compliance te zeer wordt gedrongen in de hoek van uitvoering -het afvinken van lange compliance checklists- en te weinig wordt gehoord dan wel te weinig actief is in de hoek van advisering rondom integriteit binnen de organisatie. Met een ruim beroep op Galbraith roept zij compliance officers op om de rol van countervailing power binnen de organisatie in te nemen.

Het tweede artikel beschrijft eveneens de noodzaak van innovatie in de compliance-functie. Kellermann en Bezoen beschrijven de nationale en Europese wet- en regelgeving, maar benadrukken dat compliance meer moet zijn dan dat, en zich moet richten op een cultuur van 'integer handelen' binnen de organisatie, op formele en informele integriteit. Het vermeende spanningsveld tussen commercialiteit en compliance wordt aan de hand van voorbeelden besproken, en daarin wordt de rol van zowel de compliance-afdeling als de toezichthouder beschreven. In lijn met Bleker-van Eyk roepen ook Kellermann en Bezoen op tot een compliance-functie die zich niet beperkt tot het afvinken van lijstjes, maar tot een afdeling die de business helpt om tot het juiste gedrag te komen. Niet primair door te straffen, maar door de spiegel voor te houden, op gepaste wijze tegengeluid te laten horen, en door kennis te delen.

Van den Ende en De Boer bespreken een heel andere kant van compliance, namelijk die van compliance rondom verantwoordingsinformatie. Met name behandelen zij de internationale opmars - al of niet op grond van verplichtstelling- van XBRL als standaardtaal in financiële en niet-financiële verantwoordingen. Zij beschrijven de voordelen uit oogpunt van onderlinge vergelijkbaarheid, accuratesse en efficiency, maar de eerlijkheid gebiedt te zeggen dat die voordelen met name voor de ontvangende partij evident zijn. Voor een bre- 
de acceptatie van rapportage op basis van XBRL is het noodzakelijk dat ook de aanleverende partij voordelen ziet. Ketendenken is belangrijk, maar het leggen van de juiste prikkels in de gehele keten voor alle partijen is een stap die niet moet worden overgeslagen.

De vierde bijdrage is van De Swart, Wille en Majoor. Weer een andere dimensie van het compliance domein dit keer, namelijk de accountantscontrole rondom financiële verantwoording. Data analytics wordt in veel domeinen gezien als een bron van innovatie, zeker ook binnen de accountancy. De auteurs presenteren data analytics evenwel in een sluitend statistisch kader, meer precies in een Bayesiaans model, waarbij de prior-verdeling berekend wordt aan de hand van de inschattingen aangaande het inherente, het interne beheersings- en het cijferanalyserisico. Ofwel, zoals intimi snappen, de linkerkant van het audit risk model, hetgeen de auteurs heeft verleid om deze methode het 'Push Left'-principe te noemen. De auteurs toetsen hun methode aan de gangbare audit standaarden en concluderen dat deze daarbinnen past, maar dat nadere aanscherping van de regelgeving gewenst is.
De vijfde en laatste bijdrage is van Majoor en Polman, en gaat eveneens over het compliance-domein 'accountancy'. Meer precies over de opleidingsaspecten van de accountant van de toekomst. De auteurs vergelijken een tweetal recent verschenen rapporten over dit onderwerp. Zij concluderen dat het accountantsberoep de komende tijd een belangrijke transitie door zal maken, en dat er innovaties zullen plaatsvinden in het object van controle, de wijze waarop wordt gecontroleerd en de rapportage van de bevindingen. Onderwerpen als strategie, ICT, corporate governance, ethiek en risicomanagement zullen belangrijk meer aandacht moeten krijgen dan nu het geval is, en ook attitude en communicatieve vaardigheden zullen in een dynamische nieuwe omgeving beter ontwikkeld moeten worden.

$\mathrm{Al}$ met al een mooi themanummer, waar het thema compliance breed wordt neergezet, maar steeds weer vanuit het perspectief van ingrijpende vernieuwing. Veel leesplezier! 